\title{
Alkitab Sebagai Buku Pegangan Orang Kristen (Ketidakbersalahan Alkitab)
}

\author{
Yunianto, Hani Rohayani ${ }^{1{ }^{*}}$
}

1) Sekolah Tinggi Teologi Tawangmangu, Indonesia

*) E-mail: petrusyunianto@gmail.com

\begin{abstract}
Abstrak
Ada orang Kristen yang mempercayai Alkitab sebagai pegangan hidup yang tidak memiliki kesalahan, namun sebagian orang Kristen memiliki keraguan akan hal tersebut. Perdebatan ini muncul setelah adanya kelompokkelompok yang memberikan kritik kepada Alkitab, yang kemudian disebut sebagai kelompok Kritik Tinggi (Higher Criticism) dan Kritik Rendah (Lower Criticism). Dari kritik-kritik yang ditujukan kepada Alkitab ini, maka munculah keraguan dan sikap terhadap Alkitab, bahwa Alkitab memiliki kesalahan. Pada makalah ini penulis hendak memberikan paparan tentang ketidakbersalahan Alkitab atau dalam ilmu teologi lebih dikenal dengan istilah Ineransi Alkitab agar orang Kristen memiliki keyakinan yang teguh terhadap buku pengangan yang harus dipercayai yaitu Alkitab. Dalam makalah ini penulis menggunakan metode penelitian kualitatif dengan menggunakan pendekatan studi pustaka. Penulis berusaha memaparkan bahwa Alkitab yang dipercayai sebagai buku pegangan orang Kristen adalah kebenaran Allah yang harus dipercayai dan diterima dengan iman.
\end{abstract}

Kata-Kata Kunci: Alkitab; Kristen: Pegangan Hidup; Ketidakbersalahan Alkitab.

\section{Abstract}

There are Christians who believe in the Bible as a guide to a life that is infallible, but some Christians have doubts about it. This debate arose after the 
existence of groups that gave criticism to the Bible, which were then referred to as the Higher Criticism and Lower Criticism groups. From these criticisms directed at the Bible, doubts and attitudes arise towards the Bible, that the Bible has errors. In this paper, the author wants to provide an explanation of the inerrancy of the Bible or in theology, better known as the inerrancy of the Bible, so that Christians have firm belief in the book that must be trusted, namely the Bible. In this paper, the author uses a qualitative research method using a literature study approach. The author tries to explain that the Bible which is believed to be a Christian handbook is God's truth that must be believed and accepted by faith.

Keywords: Bible; Bible Inerrancy: Christian: Way of Life.

\section{Pendahuluan}

Alkitab merupakan buku pegangan bagi orang Kristen dan telah dikanonkan sejak abad ke-3M. ${ }^{1}$ Hasil pengkanonan tersebut berhasil mengumpulkan 39 Kitab di Perjanjian Lama dan 27 Kitab di Perjanjian Baru, yang kemudian disatukan menjadi satu buku yang kemudian diberi nama Alkitab. Istilah "Alkitab" sendiri merupakan serapan dari bahasa Arab yang dapat berarti kumpulan kitab-kitab. Alkitab sendiri ditulis oleh orang-orang yang berbeda dan tempat yang berbeda serta waktu yang berbeda satu sama lain. $^{2}$

Sejak ditetapkannya atau dikanonkannya Alkitab sebagai buku pegangan hidup orang Kristen. Maka orang Kristen mempercayai bahwa Alkitab merupakan pernyataan khusus yang membuat semua orang yang membacanya dapat mengetahui dan mengenal sejarah umat Tuhan yang dituliskan di dalam Alkitab. Alkitab menceritakan tentang pekerjaan-pekerjaan Allah yang besar dan bercerita mengenai hubungan antara Allah dan manusia.

Meskipun Alkitab sudah diterima sebagai buku pegangan bagi orang Kristen, bukan berarti kemudian dapat diterima begitu saja bagi kalangan umum. Dalam sejarah perkembangan perjalanan Alkitab dari masa ke masa, maka Alkitab mulai mengalami tantangan. Ada sebagian yang mempertanyakan keasliaannya, ada yang beranggapan bahwa Alkitab berisi Firman Allah dan bukan Firman Allah sepenuhnya. Marcion misalnya, berpendapat bahwa Alkitab

\footnotetext{
${ }^{1}$ Willi Marxsen, Pengantar Perjanjian Baru (Jakarta: BPK Gunung Mulia, 2008), xviii.

${ }^{2}$ Ratri Kusuma Wijaya, “Alkitab Adalah Firman Allah Yang Tanpa Salah,” Rhema 1, no. $2(2015)$.
} 
Perjanjian Lama tidak diperlukan lagi bagi orang Kristen Perjanjian Baru ${ }^{3}$. Bahkan kemudian yang menjadi puncaknya, Alkitab mulai diragukan dan dipercayai banyak kesalahan-kesalahan yang terdapat di dalamnya, sehingga Alkitab sudah tidak dapat lagi disebut relevan bagi kebenaran atau pegangan bagi orang Kristen.

Kelompok yang mengkritisi Alkitab dengan cara meragukan dan mempertanyakan keaslian Alkitab mulai bermunculan setelah jaman reformasi dan jaman renaissance. Sisi positif dari pergerakan reformasi adalah adanya semangat untuk mengembalikan kitab suci sebagai pedoman hidup manusia, yang boleh dibaca, dan direnungkan secara pribadi. Ketika memulai gerakan reformasi, Marthin Luther merumuskan: Sola Fide, Sola Gratia, dan Sola Scriptura. Pada masa inilah orang-orang Kristen mulai membaca kitab sucinya masing-masing. Namun demikian dalam perkembangannya, justru muncul sisi negatif dari gerakan Reformasi ini. Ketika orang diberi keleluasaan dalam menafsirkan Alkitab, tanpa bimbingan dari pemimpin rohani, justru sering menimbulkan tafsiran-tafsiran yang kemudian dapat menyesatkan diri dan orang lain. Dan puncaknya adalah ketika Alkitab akhirnya dipertanyakan atau diragukan baik dari sisi isi maupun tulisannya.

Salah satu yang muncul berkaitan dengan persoalan Alkitab adalah adanya Metode Kritik Alkitab ${ }^{4}$. Kritik Alkitab ini dibagi menjadi dua kelompok, yaitu: Kritik Tinggi (Higher Criticism) dan Kritik Rendah (Lower Criticism). Kritik Rendah ini acapkali diidentikkan dengan Kritik Teks (Textual Criticism) serta merupakan fondasi dari seluruh bentuk kritik Alkitab. Kritik Rendah membahas hal-hal yang berkenaan dengan unsur-unsur sejarah; bahasa-secara khusus unsur teks dan gramatikal-yang tertulis dalam naskah atau teks cetakan, salinansalinan kuno, dan sumber-sumber pemberita lain yang resmi, sehingga dianggap bisa membantu untuk memahami teks Alkitab secara mendalam ${ }^{5}$.

\footnotetext{
${ }^{3}$ Bernhard Lohse, Pengantar Sejarah Dogma Kristen (Jakarta: BPK Gunung Mulia, 1989).

${ }^{4}$ Criticism berarti suatu pendapat atau tindakan mengadili. Kata ini diturunkan dari kata kerja bahasa Yunani (...[krino]) berarti menilai, menguji, meneruskan tuduhan kepada..., atau menetapkan. Apabila kata ini dipakai di bidang kesusatraan maka berarti menunjukkan pemikiran - bukan mengacu pada usaha mencari-cari kesalahan-tetapi menilai kebaikan serta kejelekan dari sesuatu hal secara terus terang, obyektif, jugaadil. Dengan demikian criticism adalah suatu usaha untuk melakukan penilaian yang tidak memihak. Josh McDowell, Apologetika : Volume II (Malang: Gandum Mas, 2003).

${ }^{5}$ Wisma Pandia, "Kritik Tinggi Terhadap Alkitab" (Tangerang: Sekolah Tinggi Theologi Philadelphia, n.d.), 4.
} 
Higher Criticism (Kritik Tinggi) adalah suatu studi tentang Alkitab yang mencoba mengkritisi isu-isu yang terdiri dari: bentuk naskah, bahasan serta argumen dari kitab lain; ciri serta hubungannya dengan teks; keterkaitan antar perikop, situasi yang diketahui penulis, dan hal-hal lain yang berkaitan dengan penulis. Kritik Tinggi sering dipakai sebagai alat untuk membuktikan keaslian Alkitab. ${ }^{6}$

Apabila kritik-kritik Alkitab tersebut masih berlanjut, tentunya hal ini memberikan pengaruh kepada orang Kristen dalam hal mempercayai kebenaran Alkitab sebagai pegangan hidup. Hal ini menjadi penting, sebab Alkitab adalah Firman Allah, dimana seluruh iman Kristen ditegakkan. Apabila pengertian orang Kristen terhadap Alkitab salah, maka bangunan iman Kristen pasti juga akan salah.

Layaknya seseorang yang tidak memiliki pegangan hidup secara pasti, maka hidupnya akan mudah diombang-ambingkan oleh situasi dan keadaan yang terjadi dalam kehidupan orang Kristen. Sebaliknya, jika orang Kristen memiliki kepercayaan yang kuat terhadap pengangan hidup mereka yaitu Alkitab yang tidak diragukan kebenarannya, maka hidup mereka tidak mudah untuk diombang-ambingkan. ${ }^{7}$ Berdasarkan latar belakang tersebut, pokok penelitian dari tulisan ini adalah tentang Alkitab sebagai pegangan hidup orang Kristen yang tanpa salah. Adapun tujuan penelitian ini adalah supaya pembaca mengerti tentang pentingnya doktrin Alkitab dengan benar dan menjadikan kebenaran itu sebagai pegangan dalam hidupnya. Dengan demikian, diharapkan kebenaran-kebenaran dari hasil perenungan Alkitab yang adalah Firman Allah, dapat mengubahkan hidup setiap orang yang memegang Alkitab sebagai Firman Allah dalam hidup sehari-hari.

\section{Metode Penelitian}

Penelitian ini menggunakan metode kualitatif dengan menggunakan pendekatan deskriptif analisis, dimana penulis mendeskripsikan atau memberikan gambaran terhadap objek yang diteliti melalui data-data yang sudah terkumpul. Dalam hal ini penulis akan mendeskripsikan beberapa alasan kenapa Alkitab diragukan sebagai buku pegangan bagi orang Kristen karena adanya

\footnotetext{
${ }^{6}$ Arif Wicaksono, "Pandangan Kekristenan Terhadap Higher Criticism," FIDEI: Jurnal Teologi Sistematika dan Praktika 1, no. 1 (2018): 115-131.

${ }^{7}$ David Eko Setiawan, "Konsep Keselamatan Dalam Universalisme Ditinjau Dari Soteriologi Kristen: Suatu Refleksi Pastoral," FIDEI: Jurnal Teologi Sistematika dan Praktika 1, no. 2 (2018): 250-169.
} 
pandangan tentang Kritik Alkitab. Kemudian, data-data tersebut akan diolah dan dianalisis untuk ditarik kesimpulan oleh penulis. Selain itu, peneliti juga menggunakan studi kepustakaan. Pengumpulan data dilakukan dengan cara mengumpulkan berbagai informasi mengenai Alkitab sebagai buku pegangan orang Kristen yang dapat dipercaya dan tidak memiliki kebersalahan yaitu dari buku-buku atau artikel-artikel yang berkaitan dengan Alkitab sebagai buku pegangan orang Kristen.

\section{Pembahasan dan Hasil}

\section{Teks dan Penulisan Ulang Perjanjian Lama}

Umat Kristen sudah menerima 39 Kitab dalam Alkitab Perjanjian Lama. Dalam iman orang Kristen, seluruh kitab Perjanjian Lama dipercayai sebagai pewahyuan dari Allah yang diturunkan kepada manusia sebagai tuntunan hidup. Dalam kutipan Robert Coote dan David Robert Ord, yang telah dikutip oleh Yohanes Krismantyo, dijelaskan bahwa Alkitab adalah firman Allah yang diinspirasi secara illahi dan dalam penerimaannya tidak perlu dipertanyakan ${ }^{8}$.

Seluruh kitab Perjanjian Lama masih dipakai oleh orang Kristen sampai sekarang, meskipun orang Kristen juga telah memiliki seluruh kitab Perjanjian Baru. Keberadaan semua kitab Perjanjian Lama tidak dapat dipisahkan dengan Perjanjian Baru yang sudah menjadi buku berupa Alkitab. Alasannya supaya sejarah keselamatan manusia yang telah direncanakan Allah dalam Perjanjian Lama tergenapi dalam Perjanjian Baru. Oleh karena itu umat Kristen tidak dapat meninggalkan sejarah Perjanjian Lama.

Meskipun Alkitab Perjanjian Lama dan Perjanjian Baru yang sekarang dimiliki umat Kristen bukan naskah asli, tetapi hal tersebut tidak membuat orang Kristen menjadi apatis dan kemudian tidak mempercayai keberadaan kitab-kitab Suci, baik Alkitab Perjanjian Lama maupun Alkitab Perjanjian Baru. Umat Kristen meyakini bahwa Alkitab ditulis oleh para penulis yang menerima pewahyuan dari Allah. Alkitab juga diterima sebagai buku yang bisa membawa manusia untuk mengenal sejarah keselamatan,sekaligus menjadi buku pegangan hidup bagi umat Kristen dalam menjalani hidupnya di dunia. ${ }^{9}$

Dalam proses penyalinan Alkitab, khususnya Alkitab Perjanjian Lama, kitab-kitab Perjanjian Lama tidak dicetak menurut urutan waktu penulisannya.

\footnotetext{
${ }^{8}$ Yohanes Krismantyo Susanta, Mengenal Dunia Perjanjian Lama: Suatu Pengantar (Kekata Publisher, 2018), 1.

${ }^{9}$ Hardi Budiyana, "Ineransi Alkitab Sebagai Dasar Kurikulum Pendidikan Kristen," Jurnal Teologi Berita Hidup 3, no. 2 (2021).
} 
Kitab-kitab yang dikelompokkan dalam Perjanjian Lama diyakini ditulis oleh para penulis yang berbeda, secara geografis dari tempat berbeda, serta waktu penulisan berbeda juga. ${ }^{10}$ Perlu dimengerti bahwa proses penyalinan ulang kitab-kitab Perjanjian Lama memerlukan ketelitian yang mendalam dan proses penyalinan ini dilakukan secara manual yaitu dengan ditulis tangan.

Huruf Ibrani merupakan huruf yang digunakan oleh sebagian besar penulis kitab-kitab Perjanjian Lama meskipun ada sebagian yang menggunakan bahasa Aram. Manuskrip-manuskrip Perjanjian Lama yang ditemukan dalam bahasa Ibrani dan bahasa Aram kemudian akan diteliti dengan begitu rupa, untuk dilihat keontetikkannya dan sekaligus untuk menghindari salah tulis dalam proses penyalinannya. Bangsa Yahudi memandang bahwa Alkitab ini begitu penting, itu sebabnya maka manuskrip-manuskrip tersebut dikumpukan untuk kemudian dikanonkan sesuai dengan standar pengkanonisasian. ${ }^{11}$

Teks

Para pemimpin agama Yahudi mencoba melakukan usaha-usaha dalam rangka mengkonsolidasi serta memurnikan agama mereka. Hal ini dilakukan sekitar akhir abad pertama Masehi, salah satunya adalah dengan ditentukannya teks yang normatif untuk Perjanjian Lama berbahasa Ibrani. Para Massoret, yaitu sebutan bagi para pemimpin agama Yahudi saat itu, tentu sangat berhati-hati dan berusaha penuh dalam mendokumentasikan serta menyebarluaskan teks yang sudah beserta tafsirannya. Memang, pada mulanya tafsiran tersebut berbentuk lisanserta dituturkan secara turun temurun. Namun seiring berjalannya waktu, tafsiran itu mulai dibuat tertulis di bagian pinggir halaman teks, berisi penjelasan makna dari teks dimaksud. Teks Perjanjian Lama berbahasa Ibrani yang berupa teks standar yang normatif tersebut kemudian dinamakan teks Massorah. ${ }^{12}$

Sebelum teks Massorah ini ada, sebenarnya sudah ditemukan teks-teks sebagai buku Perjanjian Lama. Misalnya saja gulungan-gulungan bertuliskan manuskrip yang ditemukan di Qumran oleh para ahli atau ditemukan pada

${ }^{10}$ S. Wismoady Wahono, Di Sini Kutemukan : Petunjuk Mempelajari Dan Mengajarkan Alkitab (Jakarta: BPK Gunung Mulia, 1986), 19.

${ }^{11}$ Yudi Jatmiko, "Konsep Otoritas Alkitab Di Hadapan Fakta Kesalahan Tekstual: Sebuah Diskusi Teologis," Veritas: Jurnal Teologi dan Pelayanan 16, no. 1 (2017).

${ }^{12}$ S. Wismoady Wahoho, Di Sini Kutemukan (Jakarta: BPK Gunung Mulia, 1986), 44. 
sebuah genizah ${ }^{13}$ di Kairo. Kebanyakan manuskrip yang kembali ditemukan ini berasal dari abad ke-2 SM, masa sebelum teks Massorah ada. Walaupun demikian, manuskrip-manuskrip tersebut sangatlah bermanfaat untuk studi kritis teks-teks Perjanjian Lama.

\section{Penulisan Ulang Perjanjian Lama}

Naskah Perjanjian Lama mula-mula, ditulis dalam bahasa Ibrani, namun huruf yang dipakai tidak dalam bentuk huruf-huruf vokal. Penulisannya pun belum ada pemisahan kata secara jelas, melainkan hanya berupa baris berlajurlajur supaya menghemat media penulisan. Oleh para Mazoretlah teks Perjanjian Lama tersebut dipilah ayat per ayat, kemudian ditambahkan huruf vokal atau penanda huruf hidup, serta tanda baca. Proses pemindahan teks yang dilakukan kaum Massoret yang adalah para cendekiawan dan ahli kitab ini memerlukan waktu yang cukup lama, sekitar tahun 500 - 900 TM. Dengan adanya Perjanjian Lama Ibrani yang kemudian dikenal sebagai teks Masoret (MT) merupakan bukti hasil kerja keras mereka dalam memelihara Alkitab Ibrani. ${ }^{14}$

Teks Massoret sudah disusun menjadi bentuk yang tetap kurang lebih pada tahun 500 M. Naskah-naskah yang ada kemudian diketahui bahwa merupakan naskah yang sama dengan naskah padaabad $9 \mathrm{M}$. Ini menjadi bukti bahwa para Mazoret melakukan penyalinan naskah TANAKH dalam bahasa Ibrani dengan sangat teliti. Wheeler Robinson menggambarkan betapa rumitnya kaum Massoret dalam menerjemahkan dan menyalin ulang naskah Alkitab, yaitu dengan menggunakan suatu sistem yang komples demi mencegah terjadinya kesalahan dalam penulisan. Dia menjelaskan bahwa: semua yang bisa dihitung akan dihitung dengan teliti. Maksudnya adalah, kaum Massoret akan menghitung kemunculan dari setiap alfabet dalam sebuah kitab. Mereka akan memberi tanda huruf tengah di Pentatheuk juga huruf tengah pada semua Alkitab Ibrani, kemudian membuat perhitungan yang lebih rumit lagi. ${ }^{15} \mathrm{Hal}$ senada juga dijelaskan oleh Sir F. Kenyon. Ia memaparkan bahwa selain mencatat variasi-variasi dari sisi perbedaan tradisi, bentuk penulisan, maupun perkiraan. Para ahli ini pun melakukan penghitungan yang bisa saja dinilai

\footnotetext{
${ }^{13}$ Genizah adalah tempat penyimpanan gulungan manuskrip yang sudah tidak lagi digunakan dalam ibadah tetapi gulungan ini tidak dibuang karena masih dianggap sesuatu yang suci.

${ }^{14}$ Andrew E. \& John H. Walton Hill, Survei Perjanjian Lama : Pembentukan Kitab-Kitab Perjanjian Lama (Malang: Gandum Mas, 1991), 19-27.

15 "Naskah Perjanjian Lama: Masorah, Laut Mati, Septuaginta Etc. - Sarapan Pagi Biblika," n.d. (diakses 2 November 2018).
} 
bahwa penghitungan tersebut seakan-akan tidak ada hubungannya dengan penelitian sebuah teks. Tidak sampai disitu saja, ayat-ayat, kata-kata, serta huruf tertentu dari satu kitab tertentu diberi nomor. Kata tengah juga setiap huruf tengah mereka hitung, kemudian semua ayat yang mengandung huruf dalam alef-bet mereka beri tanda tertentu. ${ }^{16}$

Dari fakta di atas terlihat bahwa para Massoret sangat berusaha dalam meminimalisir kesalahan dalam penyalinan teks Perjanjian Lama Ibrani. Benarlah pendapat Flavius Josephus yang adalah sejarawan Yahudi, dia menjelaskan bahwa hal tersebut menjadi bukti praktis betapa kita sangat menghargai Kitab Suci. Sekalipun waktu yang dilalui sudah sangat lampau tetapi tidak seorang pun yang berani menghilangkan atau mengurangi, menambahkan, ataupun mengubah sekalipun hanya satu suku kata dari teks tersebu. Ini adalah naluri dan sudah menjadi budaya turun-menurun di antara orang Yahudi bahwa Kitab Suci diterima dan diperlakukan secara hormat karena itu adalah perintah Allah. Mereka akan taat kepada Kitab Suci bahkan apabila diperlukan mereka rela mati untuknya. ${ }^{17}$

\section{Kepercayaan Kepada Perjanjian Lama}

Para penulis Alkitab Perjanjian Lama diyakini mendapatkan wahyu dari Allah dalam menuliskannya, sekalipun ditulis oleh orang yang berbeda dan pada kurun waktu yang berbeda pula. Keyakinan inilah yang menjadikan Alkitab diterima sebagai Firman Allah, memiliki otoritas, dan diyakini sebagaibuku petunjuk hidup bagi orang Kristen. Inilah yang dimaksud dengan Alkitab bersifat autopistos, ${ }^{18}$ yaitu Alkitab menyinarkan sendiri kewibawaan ilahinya. Dengan pertolongan Roh Kudus seseorang dimampukan untuk menangkap terang tersebut. Dalam Confessio Belgica (Pengakuan Iman Gereja-gereja di Nederland), di sana dijelaskan bahwa seseorang bisa mempercayai segala sesuatu yang tertulis dalam Alkitab, bukan karena gereja menerima, meyakinin, atau menganggapnya seperti itu. Hal ini dikarenakan Roh Kudus yang bersaksi di dalam hati seseorang bahwa Alkitab adalah wahyu Allah. ${ }^{19}$

${ }^{16}$ Frederic G. Kenyon, Our Bible and the Anchient Manuscripts (New York: Harper \& Brothers, 1941), 38.

${ }^{17}$ Flavius Josephus, “'Flavius Josephus Against Apion', Josephus Complete Works” (Grand Rapids: Kregel Publication, 1960), 179-180.

${ }^{18}$ autopistos artinya membuktikan Sendiri Keotentikannya.

${ }^{19}$ J.D. Douglas, ed., Ensiklopedi Alkitab Masa Kini; Jilid A-L : Kanon Perjanjian Lama (Jakarta: Yayasan Komunikasi Bina Kasih, 1993), 510-511. 
Ada syarat-syarat yang ditentukan dalam menetapkan bahwa suatu naskah bisa masuk dalam kanonisasi Perjanjian Lama. Andrew E. Hill \& John H. Walton menuliskan 4 alasan sebagai syarat kanonisasi Perjanjian Lama. Pertama,ada bukti-bukti nyata dari Alkitab itu sendiri. Alkitab sendiri memberikan satu informasi tentang perkataan yang diucapkan oleh Allah sendiri dan bukan manusia. Seperti misalnya ada kata "Dan berfirmanlah Allah...", atau kata "Tuhan berkata....". Kedua, para penulis Alkitab adalah orang-orang yang dituntun Roh Allah. Umumnya, mereka adalah orang-orang yang dikehendaki oleh Allah secara langsung dan biasanya menduduki suatu jabatan misalnya nabi, imam, raja serta hakim. Ketiga, kuasa Allah sangat mempengaruhi tulisantulisan mereka. Dalam hal ini diyakini bahwa apabila kata-kata yang dituliskan tersebut merupakan perkataan Ilahi, tentu tulisan itu mengandung kebenaran, berkuasa untuk mengajar dan mengubah hidup seseorang. Keempat, terdapat bukti berkenaan dengan keaslian naskah juga tulisan. Salah satu pendukung dari keotentikan suatu tulisan ini adalah adanya bukti-bukti arkeologi.Kelima, naskah tersebut diterima secara aklamasi oleh orang Israel dan para pemimpin agama ${ }^{20}$.

Bagi orang Yahudi serta orang Kristen, Perjanjian Lama yang dipercaya sebagai Firman Allah di dalamnya ada 39 buah kitab. Adapun pembagiannya, sebagai berikut: Pertama, Kitab Taurat yaitu Kitab Kejadian, Keluaran, Imamat, Bilangan, serta Ulangan. Kedua, Kitab Sejarah. Sejarah pertama yaitu: Kitab Yosua, Hakim-hakim, Rut, 1 Samuel, 2 Samuel, 1 Raja-raja, 2 Raja-raja. Sejarah kedua yaitu : Kitab 1Tawarikh, 2 Tawarikh, Ezra, Nehemia, Ester. Keempat, Kitab Sastra yaitu: Kitab Ayub,Mazmur, Amsal, Pengkhotbah, serta Kidung Agung. Keempat, Kitab Nubuat. Di dalamnya terdapat dua bagian yaitu Kitab-kitab nabi besaryang di dalamnya ada Kitab Yesaya, Yeremia, Ratapan, Yehezkiel dan Daniel. Bagian kedua yaitu Kitab-kitab nabi-nabi kecil, yang terdiri dari : Kitab Hosea, Yoel, Amos, Obaja, Yunus, Mikha, Nahum, Habakuk, Zefanya, Hagai, Zakaria, dan Maleakhi ${ }^{21}$.

Perjanjian Lama yang di dalamnya terdapat 39 Kitab ini hanya diyakini oleh orang Yahudi serta orang Kristen. Katolik masih mempercayai Kitab Apokripa, yang kemudian ditambahkan dalam kitab Perjanjian Lama mereka. Kitab-kitab yang ditambahkan dan diyakini oleh Katolik diantaranya: Riwayat Tobit, Riwayat Yudit, Kitab I \& II Makabe, Kebijaksaan Salomo, Hikmat Yesus

${ }^{20}$ Andrew E. Hill, Survei Perjanjian Lama (Malang: Penerbit Gandum Mas, 1996).

${ }^{21}$ David Baker, ed., Mari Mengenal Perjanjian Lama : Susunan Perjanjian Lama Kanon (Jakarta: BPK Gunung Mulia, 1997), 15-20. 
bin Sirakh, Kitab Barukh serta Surat Yeremia, tambahan-tambahan pada Kitab Eseter dan Daniel.

\section{Teks dan Penulisan Ulang Perjanjian Baru}

Alkitab Perjanjian Baru yang diterima sekarang ini berjumlah 27 Kitab. Sebagaimana dengan Perjanjian Lama, naskah dalam Perjanjian Baru ini ditulis oleh penulis yang berbeda, di tempat yang berbeda, serta pada kurun waktu yang berbeda juga. Terbentuknya Perjanjian Baru yang hari ini di tangan kita, sebenarnya telah melalui proses dan seleksi perkamen-perkamen yang ditemukan.

Tulisan-tulisan dalam Perjanjian Baru merupakan salinan tulisan-tulisan tangan yang menjadi bagian kitab Perjanjian Baru pada Alkitab yang diterima orang Kristen. Tulisan Perjanjian Baru sebenarnya sudah lama terlestarikan. Berjumlah lebih dari 5.800 naskah bahasa Yunani lengkap atau terfragmentasi, 10.000 naskah bahasa Latin dan 9.300 naskah berbahasa kuno yang lain termasuk bahasa Suryani, bahasa Slavik, bahasa Gothik, bahasa Ge'ez (Etiopia), bahasa Koptik dan bahasa Armenia. Kurun waktu penulisan naskah tersebut berkisar mulai $125 \mathrm{M}^{22}$ sampai dengan adanya percetakan di Jerman sekitar abad XV. Naskah-naskah ini mayoritas dari abad X.

Bruce M. Metzger menjelaskan bahwa pelestarian tek-teks naskah kuno ini perlu ditimbang menjadi sesuatu hal yang dipandang baik. Iliad yang adalah karya dariHomer, sudah dilestarikan ke dalam 457 buah naskah papirus, 2 uncial, dan 188 minuscule. Dari semua naskah tragedi, Euripides memiliki naskah terbanyak. Sampai sekarang masih ada naskah yang meliputi 54 papirus beserta 276 perkamen. Hampir semua naskah itu bertarikh zaman Bizantin. Selisih waktu dari penulisan naskah-naskah Perjanjian Baru juga salinan naskah yang ada sekarang bisa dikatakan sangatlah singkat, tidak sampai melebihi satu milenium ${ }^{23}$.

Proses penyalinan naskah-naskah Perjanjian Baru dilakukan oleh masyarakat selama 1.400 tahun. Mereka ini tersebar ke banyak komunitas di benua yang berbeda-beda. Kendatipun demikian, isi naskah tidak mengalami perubahan yang signifikan. Penulisan naskah asli dilakukan di atas kulit dan papyrus. Baik kulit maupun papyrus ini bahan yang mudah rusak termakan

\footnotetext{
${ }^{22}$ Naskah papirus dari John Rylands,merupakan fragmen tertua yang isinya merupakan salinan Injil Yohanes.

${ }^{23}$ Bruce M. Metzger and Bart D. Ehrman, The Text Of The New Testament: Its Transmission, Corruption, and Restoration (USA: Oxford University Press, 2005), 33-35.
} 
umur, itu sebabnya harus terus disalin ulang. Inilah faktor yang menyebabkan naskah asli sudah tidak dapat ditemukan sekarang. Naskah yang ada saat ini merupakan salinan dari naskah asli itu.

David menjelaskan bahwa sekarang semakin banyak ditemukan catatan dari masa lalu sehingga bisa dijadikan bukti pendukung untuk tulisan kitabyang sudah ada.Secara khusus kitab Perjanjian Baru, mempunyai 5,300 naskah juga fragmenyang berbahasa Yunani. Selain itu, ada 10.000 naskah dalam bahasa latin Vulgate juga sejumlah 9,300 naskah yang sudah tua yang merupakan terjemahan bahasa lain. Bisa dikatakan Perjanjian Baru mempunyai 24,000 lebih salinan naskah yang bisa digunakan.

Hal lain yang perlu diperhatikan juga bahwa manuskrip, penyalinan naskah asli dengan cara ditulis tangan Perjanjian Baru tidak hanya satu. Apabila seseorang memerlukan salinan, orang tersebut harus menyalin ulang tulisan tersebut dengan cara ditulis tangan. Itu sebabnya salinan Perjanjian Baru berbahasa Yunani begitu beraneka macam. Ada banyak ragam codex yang ditemukan, tapi yang paling populer hanya ada dua naskah. Naskah pertama adalah naskah Stephanus atau biasa disebut Textus Receptus (TR). Textus Receptus adalah naskah yang diterima dan ditujukan pada Alkitab Perjanjian Baru berbahasa Yunani. Perjanjian Baru Yunani ini diterbitkan pada tahun 1550. Karya yang paling umum adalah karya Erasmus dari Rotterdam. Textus receptus ini adalah naskah yang sangat umum dipakai sampai abad ke-19. Akan tetapi, banyak penemuan-penemuan baru dan perkembangan dalam bidang kritik teks. Kritik teks inilah yang kemudian memaksa diterbitkannya naskah Yunani yang disesuaikan, serta menjadi dasar misalnya untuk misalnya RV di tahun 1881. Textus Receptus dalam Perjanjian Lama berbahasa Ibrani ini merujuk pada Alkitab Rabinik Kedua. Pada tahun 1524 Alkitab ini diterbitkan di Venisia. Naskah ini adalah terjemahan dasar dari Alkitab Luther Jerman. Pada masa reformasi, terjemahan Perjanjian Baru sebagian besar memakai naskah Alkitab Luther Jerman sebagai sumber dari terjemahannya. Selain itu, dalam bahasa Inggris Perjanjian Baru ini ditulis oleh William Tyndale. Alkitab versi King James juga memakai naskah yang sama sebagai sumber penulisannya. Textus Receptus adalah naskah Barat (Western-typetext) yang berasal dari manuskrip yang sudah ada sejak abad ke-7 Masehi.

Kemudian yang kedua adalah naskah Westcott/Hort (WH) yang diteruskan oleh Nestle/K. Aland. Naskah WH dikenal sebagai Revised Text. Teks Bizantin atau Teks Mayoritas (bahasa Inggris: Byzantine text-type atau Majority Text) merupakan bentuk teks yang kemudian dipakai sebagai kritik teks dalam 
Alkitab. Dimana jenis teks ini dipergunakan untuk mengklasifikasi karakter tekstual naskah-naskah Alkitab terkhusus bagian kitab Perjanjian Baru dalam bahasa Yunani Koine. Perjanjian Baru dari Gereja Ortodoks Timur (Eastern Orthodox Church atau Greek Orthodox Church), "Constantinople Patriarchate" edisi tahun 1904, berdasarkan jenis teks ini.

Meskipun terdapat sejumlah besar variasi, teks ini mendasari teks Yunani Textus Receptus yang dipakai untuk membuat terjemahan Perjanjian Baru ke berbagai bahasa daerah pada masa era Reformasi Protestan, termasuk Alkitab Versi Raja James (meskipun terjemahan-terjemahan baru yang ada sekarang umumnya menggunakan edisi "Eclectic" yang lebih mengacu kepada jenis teks Alexandria). Teks Bizantin ini juga digunakan dalam sejumlah edisi modern Gereja Ortodoks Timur, dan tradisi penggunaannya di gereja-gereja tersebut berlanjut sampai sekarang.

Teks yang digunakan di Gereja Ortodoks Yunani juga didukung sejumlah naskah bergaya minuscule yang berasal dari tahun-tahun selanjutnya. Umumnya ini dianggap sebagai teks Bizantin standar. Naskah ini berasal dari manuskrip kurang lebih pada abad ke-4 M, dan dikenal sebagai naskah Aleksandria.Salinan naskahPerjanjian Baru TR dan WH ini yang paling banyak dijadikan dasar dalam penerjemahan Alkitab berbagai versi bahasa yang ada saat ini.TR dan WH memang memiliki berbagai perbedaan, kendatipun demikian perbedaan tersebut tidak terlalu signifikan.

\section{Kepercayaan Terhadap Perjanjian Baru}

Alkitab merupakan pernyataan juga penyataan hukum, ajaran, janji serta karya Allah yang sifatnya orisinil. Sekalipun kitab-kitab Perjanjian Baru melewati suatu proses seleksi dari ribuan naskah yang ditemukan, namun hal tersebut tidak mengurangi keyakinan bahwa Perjanjian Baru ini adalah Kitab Suci. Perjanjian Baru telah diterima sebagai buku 'kelanjutan'Perjanjian Lama. Isi dari kitab-kitab Perjanjian Baru adalah penggenapan karya keselamatan yang tertulis dalam Perjanjian Lama. Keduanya telah diterima sebagai Buku Suci, buku pemberian Allah untuk manusia. ${ }^{24}$

Alkitab Perjanjian Baru merupakan kumpulan kitab yang diterima orang Kristen bersumber dari wahyu Allah. Sebagian besar ahli kitab menyepakati bahwa kanon Perjanjian Baru terdiri dari 27 kitab yang mencakup: Injil

${ }^{24}$ Henry C. Thiessen, Teologi Sistematika, ed. Vernon D. Doerksen, Revisi ke V. (Malang: Yayasan Gandum Mas, 2000), 88-90. 
Kanonik, Kisah, Surat-surat Para Rasul, serta Kitab Wahyu. Kitab-kitab dalam Perjanjian Baru ditulis pada abad pertama dan selesai sekitar tahun $150 \mathrm{M}^{25}$

Bagi kalangan Ortodoks, pengakuan otoritatif atas tulisan-tulisan ini disahkan pada konsili gereja pada tahun 397 M di Carthago. Pada momen ini dilakukan pengesahan atas 27 kitab Perjanjian Baru. Kitab-kitab ini mempunyai otoritas dalam gereja, bukan sebaliknya gereja yang mempunyai otoritas atas kitab-kitab tersebut. Hal ini bukan disebabkan karena gereja bukanlah penentu atau pencipta kanonisasi, gereja hanya mengesahkan naskah-naskah yang mempunyai ciri kanonitas. ${ }^{26}$

Sampai saat ini, Perjanjian Baru diterima gereja sebagai Kitab yang dipandang sah. Perjanjian Baru juga terus-menerus dipergunakan serta diterima umat Kristen sebagai buku yang mempunyai otoritas kebenaran. Perjanjian Baru dan Perjanjian Lama telah dikumpulkan menjadi satu buku, yang dinamakan Alkitab. Alkitab inilah yang terus dipakai sebagai buku petunjuk hidup dan buku kebenaran.

\section{Pengakuan Terhadap Ketakbersalahan Alkitab}

Alkitab telah hadir di dalam sejarah hidup manusia. Kehadirannya ini memberikan petunjuk hidup bagi manusia guna mengenal Sang Pencipta-Nya. Alkitab yang hari ini di tangan setiap pembaca, diyakini sebagai buku yang dalam proses penulisannya benar-benar dipercayai berdasarakan atas pengilhaman dari Allah. Itu sebabnya dalam kekristenan dikenal satu istilah yaitu Ineransi Alkitab. Kata inerrant berasal dari kata Latin errare yang mengimplikasikan sesuatu yang menjauhi kebenaran. Kata inerrantinimenyatakan kualitas yang bebas dari kekeliruan (exempted from error/error-free). Ineransi Alkitab adalah doktrin yang menyatakan bahwa "Alkitab, dalam bentuk naskah aslinya, tidak mengandung kesalahan atau seratus persen benar" atau "Kitab Suci dalam naskah aslinya tidak membenarkan apapun yang bertentangan dengan fakta." Dalam bagian sebelumnya telah dituliskan mengenai autopistos, dimana Alkitab membuktikan kebenarannya sendiri.

2 Timotius 3:16 menjadi alasan kuat mengapa penulis mempercayai ineransi Alkitab. Dalam ayat tersebut terdapat kata 'diilhamkan Allah'. Oleh karena diilhamkan oleh Allahlah sehingga Alkitab menjadi ineran. Roh Kudus 
membimbing para penulis untuk menuliskan isi Alkitab sebagaimana isi Alkitab yang ada sekarang. John Stott menjelaskan lebih dalam ketika seseorang hendak membahas Alkitab. Ada tiga istilah penting yang dipakai dalam menjelaskan keberadaan Alkitab. Pertama, 'penyataan', kedua, 'pengilhaman' dan ketiga 'otoritas'. ${ }^{27}$

Istilah 'penyataan' menunjuk pada prakarsa yang telah diambil Allah untuk membuat diri-Nya menjadi nyata dan dapat dikenal. Ia Allah yang transanden (jauh keberadaannya....) tetapi juga Allah yang imanen (dekat keberadaannya....). Istilah 'pengilhaman' mengacu kepada cara yang diperkenan Allah dalam rangka menyatakan diri-Nya. Dia telah menyatakan diri-Nya secara tidak penuh melalui alam semesta dan dengan sempurna di dalam Kristus. Tetapi, Allah juga telah 'berbicara' kepada orang-orang tertentu. Proses komunikasi lisan inilah yang disebut 'pengilhaman'. Istilah 'otoritas' adalah kuasa atau bobot Alkitab karena kenyataan dirinya tadi yaitu sebagai penyataan Illahi yang diberikan melalui pengilhaman Ilahi. Jika itu adalah kata-kata Allah, maka kata-kata itu berotoritas atas manusia. Sebab dibalik setiap kata yang diucapkankan seseorang berdiri pribadi yang mengucapkannya. ${ }^{28}$

Proses pembuktian dari ineransi Alkitab ini, tidak bisa lepas dari proses terbentuknya Alkitab itu sendiri. Hal ini terjalin erat sehingga menjadi kesatuan yang dapat dipercaya. Alkitab yang dipercaya merupakan kebenaran sejati dari Allah yang sesungguhnya (Yoh 17:17). Melalui proses yang dilewati itulah kita akan mampu melihat konsistensinya: ${ }^{29}$

\section{Melalui Verbal Plenary}

Proses ini merupakan proses supranatural. Dalam hal ini yang menjadi sumber utamanya adalah dari Allah serta sepenuhnya disampaikan oleh Allah (verbal plenary) kepada orang pilihan-Nya. Selain itu, Firman yang disampaikan-Nya pun adalah benar. Allah menginspirasikan Firman-Nya kepada penulis dan dengan pengawasan dari Allah langsung para penulis mencatatnya sesuai dengan yang difirmankan Allah. Satu hal yang tidak boleh diragukan adalah bahwa Firman yang diberikan Allah itu adalah atas kedaulatan-Nya sendiri, tanpa ada campur tangan manusia atau pengaruh dari manusia sehingga Allah memberikan perkataan-Nya itu. Para penulis Alkitab ini tidaklah mungkin keliru ataupun salah apalagi sampai menghilangkan

\footnotetext{
${ }^{27}$ John Stott, Memahami Isi Alkitab (Jakarta: Persekutuan Pembaca Alkitab, 1984).

${ }^{28}$ Ibid.

${ }^{29}$ Gleason L Archer, Encyclopedia of Bible Difficulties (Zondervan Pub House, 1982), 23.
} 
keakurasian Firman Tuhan. Mereka semua dipimpin Roh Kudus dalam melakukan penulisan tersebut (2 Pet. 1:21). ${ }^{30}$

\section{Melalui Salinan}

Teks naskah asli Alkitab sekalipun kemudian disalin, penyalinan ini dilakukan oleh mereka yang juga dipakai Allah, mendapatkan pengertian yang benar dari Allah sehingga tingkat kesalahan dalam penyalinan tersebut bisa dikatakan tidak ada. Para penyalin ini bukan sembarang orang, mereka adalah orang-orang terpelajar di bidangnya dan mengerti tulisan teks asli. Penyalinan ini dilakukan oleh sekretaris-sekretaris ahli taurat yang mempunyai pengertian yang memadai berkenaan dengan tulisan yang mereka salin. Dari segi waktu, penyalinan Perjanjian Baru ini memakan waktu yang tidak sebentar, sehingga bisa dikatakan bahwa akurasi dari penyalinan ini tidak perlu disangsikan. Memang saat ini naskah aslinya sudah tidak ada, tapi bukan berarti kita bisa langsung meragukan kebenaran dari salinan yang saat ini masih ada. Sebab Allah menjamin tidak ada bagian dari Firman-Nya yang akan berubah, tidak ada yang dihilangkan atau pun ditambahkan sekecil apapun (Mat. 5:18). Alkitab yang sekarang kita baca adalah hasil salinan dari naskah asli dari para penulis awal Alkitab. Sekalipun dari segi gaya bahasa sudah mengalami perubahan, akan tetapi dari sisi konsep ajaran di dalam salinan tersebut tidak ada yang berubah. Kelompok limited ineransi sering memakai konsistensi ineransi Alkitab ini untuk mempertanyakan atau bahkan meragukan ineransi Alkitab.

\section{Konfluen (Kesesuaian)}

Para penulis Alkitab tidak dipakai sebagai robot mekanis. Mereka tentu saja berbicara dengan kata-kata mereka sendiri dalam Alkitab dari awal sampai akhir (kepribadian mereka meresap dalam karya-karya mereka yang bervariasi), tetapi Allah sendiri berbicara secara kreatif. Ini berarti bahwa perkataan perkataan Alkitab merupakan perkataan manusia dan perkataan Allah pada waktu yang sama, namun akhirnya berasal dari Allah juga dan bebas dari kesalahan. ${ }^{31}$

\footnotetext{
${ }^{30}$ Kevin Tonny Rey, "Revelasi Roh Kudus Bagi Interpreter Dalam Menafsirkan Alkitab," Antusias 1, no. 3 (2011).

${ }^{31}$ W. Gary Crampton, Verbum Dei (Alkitab: Firman Allah), ed. Trivina Ambarsari and Sutjipto Subeno, Cetakan Ke. (Surabaya: Momentum, 2000), 55.
} 


\section{Perspicuity (Ketajaman)}

Doktrin ini mengenai kejelasan Alkitab. Setiap orang yang bisa membaca dapat membaca dan mengerti Alkitab. Alkitab adalah sebuah buku. Tetapi Alkitab harus diakui oleh semua pembacanya bahwa Alkitab merupakan buku yang sempurna dari Allah, dan harus dihormati juga. ${ }^{32}$

\section{Autograph}

Naskah manuskrip dari penulis-penulis awal yang mendapatkan wahyu langsung dari Allah, dan meskipun sudah tidak ada lagi sekarang, tidak mengurangi keineransian Alkitab, Allah yang sesungguhnya dapat memelihara autograph itu dengan kuasa-Nya. Dalam proses penyalinan Alkitab Allah berperan mengawasi sepenuh-Nya dalam kedaulatan-Nya. Sehingga lahir satu karya yang akurat, sebagaimana diwahyukan oleh Allah kepada para penulis. Allah dengan wibawa providensia-nya tetap terus memelihara Firman-Nya. Firman Allah diyakini tidak mungkin berubah karena Allah konsisten terhadap apa yang Ia sampaikan. Bahkanfirman-Nya dipelihara oleh Allah sendiri (Yoh. 10:35). Bukti lain juga menyatakan pembenaran penulisan Alkitab yang ada saat ini. Para ahli Alkitab yang sudah melakukan penelitian ilmiah menjelaskan bahwa kekeliruan yang terdapat dalam Alkitab hanyalah 1 dari seribu persen, dan hal itu dibiarkan Allah karena kekeliruan itu tidak mempengaruhi kebenaran Alkitab secara menyeluruh.

Dengan demikian, dari beberapa pembuktian mengenai ineransi yang melewati proses dari verbalplenary sampai pada penyalinannya, Alkitab sebagai Firman Allah tetaplah konsisten kebenarannya sejak dari awal diberikannya pada manusia. Hal ini disebabkan karena Allah yang secara penuh memberikan serta mengawasi dalam setiap proses Alkitab itu terbentuk.

\section{Simpulan}

Di tengah-tengah kemajuan informasi dan teknologi, tetap saja ada kemungkinan bahwa Alkitab terus diragukan sebagai buku yang memiliki otoritas. Orang bisa saja meragukan keberadaan Alkitab, hanya dipandang sebagai kumpulan salinan-salinan naskah yang ditemukan pada masa lampau. Alkitab sebagai buku pegangan orang Kristen sudah terbukti terpelihara oleh Allah sendiri sampai dengan hari ini. Alkitab mempunyai kualitas yang bebas dari kesalahan. Alkitab tidak mengatakan yang bertentangan dengan kenyataan. 
Alkitab mencatat sejarah secara akurat dan sempurna, yang dapat menjadi buku pegangan hidup bagi orang Kristen.

\section{Daftar Pustaka}

Archer, Gleason L. Encyclopedia of Bible Difficulties. Zondervan Pub House, 1982.

Baker, David, ed. Mari Mengenal Perjanjian Lama : Susunan Perjanjian Lama Kanon. Jakarta: BPK Gunung Mulia, 1997.

Budiyana, Hardi. "Ineransi Alkitab Sebagai Dasar Kurikulum Pendidikan Kristen.” Jurnal Teologi Berita Hidup 3, no. 2 (2021).

C. Thiessen, Henry. Teologi Sistematika. Edited by Vernon D. Doerksen. Revisi ke. Malang: Yayasan Gandum Mas, 2000.

Crampton, W. Gary. Verbum Dei (Alkitab: Firman Allah). Edited by Trivina Ambarsari and Sutjipto Subeno. Cetakan Ke. Surabaya: Momentum, 2000. Douglas, J.D., ed. Ensiklopedi Alkitab Masa Kini; Jilid A-L : Kanon Perjanjian Lama. Jakarta: Yayasan Komunikasi Bina Kasih, 1993.

Hill, Andrew E. Survei Perjanjian Lama. Malang: Penerbit Gandum Mas, 1996. Hill, Andrew E. \& John H. Walton. Survei Perjanjian Lama: Pembentukan Kitab-Kitab Perjanjian Lama. Malang: Gandum Mas, 1991.

Josephus, Flavius. “'Flavius Josephus Against Apion', Josephus Complete Works." Grand Rapids: Kregel Publication, 1960.

Kenyon, Frederic G. Our Bible and the Anchient Manuscripts. New York: Harper \& Brothers, 1941.

Lohse, Bernhard. Pengantar Sejarah Dogma Kristen. Jakarta: BPK Gunung Mulia, 1989.

Marxsen, Willi. Pengantar Perjanjian Baru. Jakarta: BPK Gunung Mulia, 2008. McDowell, Josh. Apologetika: Volume II. Malang: Gandum Mas, 2003.

Metzger, Bruce M., and Bart D. Ehrman. The Text Of The New Testament: Its Transmission, Corruption, and Restoration. USA: Oxford University Press, 2005.

Pandia, Wisma. "Kritik Tinggi Terhadap Alkitab.” Tangerang: Sekolah Tinggi Theologi Philadelphia, n.d.

Rey, Kevin Tonny. "Revelasi Roh Kudus Bagi Interpreter Dalam Menafsirkan Alkitab." Antusias 1, no. 3 (2011).

Setiawan, David Eko. "Konsep Keselamatan Dalam Universalisme Ditinjau Dari Soteriologi Kristen: Suatu Refleksi Pastoral.” FIDEI: Jurnal Teologi Sistematika dan Praktika 1, no. 2 (2018): 250-169. 
158 Fidei: Jurnal Teologi Sistematika dan Praktika, Vol. 4, No. 1, Juni 2021

Stott, John. Memahami Isi Alkitab. Jakarta: Persekutuan Pembaca Alkitab, 1984. Susanta, Yohanes Krismantyo. Mengenal Dunia Perjanjian Lama: Suatu Pengantar. Kekata Publisher, 2018.

Wahoho, S. Wismoady. Di Sini Kutemukan. Jakarta: BPK Gunung Mulia, 1986.

Wahono, S. Wismoady. Di Sini Kutemukan: Petunjuk Mempelajari Dan Mengajarkan Alkitab. Jakarta: BPK Gunung Mulia, 1986.

Wicaksono, Arif. "Pandangan Kekristenan Terhadap Higher Criticism." FIDEI: Jurnal Teologi Sistematika dan Praktika 1, no. 1 (2018): 115-131.

Wijaya, Ratri Kusuma. "Alkitab Adalah Firman Allah Yang Tanpa Salah." Rhema 1, no. 2 (2015).

Yudi Jatmiko. "Konsep Otoritas Alkitab Di Hadapan Fakta Kesalahan Tekstual: Sebuah Diskusi Teologis." Veritas: Jurnal Teologi dan Pelayanan 16, no. 1 (2017).

"Naskah Perjanjian Lama: Masorah, Laut Mati, Septuaginta Etc. - Sarapan Pagi Biblika," n.d. 